\title{
AN ANALYSIS OF STUDENT STRATEGY IN COMPLETING TOEFL READING COMPREHENSION TEST
}

\author{
Dede Rohadi Fajri \\ Universitas Banten Jaya \\ dederohadifajri@gmail.com
}

\begin{abstract}
This research aimed to find out the strategies used by students in completing TOEFL reading comprehension test, types of reading comprehension in TOEFL test that was difficult to be answered by students, the greatest challenges factor for students in completing reading comprehension in TOEFL test, and the score of the $2^{\text {nd }}$ semester students of STTIKOM Insan Unggul Cilegon-Banten. This is a descriptive qualitative study based on observation, interview, questionnaire and test as the instruments of collecting data.The sample is 20 advanced STTIKOM undergraduate students at Cilegon-Banten in Academic year 2018/2019 who were asked to do a PBT TOEFL reading comprehension test.The result showed that inference (33\%), vocabulary (40\%) and unstated details $(50 \%)$ questions are the most difficult types to be answered by students. Related to the strategy, three of the strategies (skimming and scanning, top down and guess meaning) are used by students in answering reading comprehension in TOEFL test. The greatest challenges for students in answering TOEFL reading comprehension in TOEFL test are less motivation in reading a text, less practice and they did not mastering vocabulary well. In addition, the TOEFL score of STTIKOM Insan Unggul Cilegon-Banten was insufficient to achieve standardize test or low.
\end{abstract}

Key words : strategy, reading comprehension, TOEFL test.

\section{INTRODUCTION}

The capability of mastering English language in globalization era is an important thing because it is an international language that mostly used in many countries of various field .However students at every level of education should be able to learn and master four skills of languange; listening, speaking, reading, writing. Among those four skills, reading skills remain a big problem for them since it is not only a skill of pronouncing the words, clauses or sentences correctly but also a skill of understanding what is read. As Kusuma (2016 : 3) stated that TOEFL test is proficiency test, In this research, the researcher will use TOEFL ITP test. TOEFL ITP stands for “ Institutional Testing Program ". Among three language skills tested in TOEFL, reading comprehension is the most important section ( Anjomshoa \& Zamanian, 2014) cited in Putra et al., ( 2017 ). Strategies to answer questions in reading section of a TOEFL test is recommended. Based on the writer's experience, it was discovered that the Second semester students of STTIKOM (an information and technology Institute) considered that reading section at a TOEFL test is extremely difficult. Students claim that 
they faced some problems regarding the unfamiliarity of the topic discussed in the texts. Based on the statement above, it can be concluded that reading comprehension can be something difficult and challlenging when the student lack of knowledge and unfamiliar with the strategies in reading section. Therefore, the researcher is interested to conduct a research about " An analysis of students strategy in completing TOEFL reading comprehension test

', What is strategy used by students in completing Toefl reading comprehension test?, Which Types of reading comprehension in Toefl test are difficult to be answered by students? What is the greatest challenges for students in completing reading comprehension in TOEFL test ? How is the TOEFL score of $2^{\text {nd }}$ Semester students at STTIKOM Insan Unggul Cilegon, Banten Province in Academic Year 2018/2019?

Reading comprehension has turned out as a topic that the discussions seems endles. Some experts contributed to the definition of it. According to McNamara (2007a : 3) Reading is an extraordinary achievement when one considers the number of levels and components that must be mastered. Brown (2001: 306), pointed out that " reading comprehension is a matter of developing appropriate, efficient comprehension strategies". He goes on to enumerate ten such strategies : Identify the purpose in reading, Use graphemic rules and patterns to aidd in bottom-up reading, Use different silent reading techniques for relatively rapid reading etc.

Some researcher have conducted to the students reading comprehension In TOEFL test there are : Samad et al., (2016) in his research about “ EFL students' strategies dealing common difficulties in TOEFL reading comprehension section". They investigated the undergraduate students' difficulties and their strategies in completing TOEFL reading comprehension test. Mahmud (2014) In his research “ The EFL Student's problems in answering the test of English as foreign language (TOEFL). A study in Indonesian context". His studies focus in explore the student's problems in answering the TOEFL. My research expands the finding of previous research, in this study The writer only focuses on reading comprehension in TOEFL test and try to discuss more completely about the students strategies in completing TOEFL reading comprehension test, the most difficult types question in answering TOEFL reading comprehension test, the 
greatest challenges in TOEFL reading comprehension test and the students score in TOEFL test.

\section{METHODS}

This research is aimed to analyze the strategies used by students in completing reading comprehension in TOEFL test. Therefore the researcher applied descriptive qualitative as the research design. This research conducted at STTIKOM Insan Unggul Cilegon in Banten Province, Indonesia. The researcher conducted this research on $7^{\text {th }}$ May around $14^{\text {th }}$ May 2018. The subject of this research is the $2^{\text {nd }}$ semester students of STTIKOM Insan Unggul Cilegon who had studied the

\section{Results of the test}

The following table presents the result of data from the test that had been material of reading comprehension for the test of English as a foreign language or TOEFL. In collecting data The researcher conducted in five steps as follows: Observation, test, questionnaire and documentation.

\section{FINDINGS AND DISCUSSION}

In order to analyze the research result the researcher converted the data into percentages. The percentages were gained by using the following formula.

\begin{tabular}{|l|}
\hline \multicolumn{1}{|c|}{$\mathbf{P} / \mathbf{F} \boldsymbol{x} \mathbf{1 0 0 \%}$} \\
$\mathrm{P}=$ Percentage \\
$\mathrm{F}=$ Frequency ( Number of questions \\
respondent correctly) \\
$\mathrm{N}=$ Total number of question
\end{tabular}

done by students in TOEFL reading comprehension test.

Table 2.1

Test results

\begin{tabular}{|c|c|c|c|c|}
\hline No & Reading skill & $\begin{array}{c}\text { Total } \\
\text { Questions }\end{array}$ & $\begin{array}{l}\text { Correct } \\
\text { answer }\end{array}$ & $\begin{array}{c}\text { Percentage } \\
(\%)\end{array}$ \\
\hline 1. & Answering Main idea & 7 & 6 & $85 \%$ \\
\hline 2. & Answering Stated detail & 7 & 5 & $71 \%$ \\
\hline 3 & Finding Unstated details & 6 & 3 & $50 \%$ \\
\hline 4. & $\begin{array}{l}\text { The ability to find specific } \\
\text { information }\end{array}$ & 7 & 5 & $71 \%$ \\
\hline 5 & Inference question & 6 & 2 & $33 \%$ \\
\hline 6 & Pronoun reference question & 7 & 6 & $71 \%$ \\
\hline \multirow[t]{2}{*}{7} & Vocabulary question & 10 & 4 & $40 \%$ \\
\hline & Total & 50 & 30 & $\%$ \\
\hline
\end{tabular}


The table 2.1 shows the types of questions that are considered to be the most difficult ones in TOEFL reading comprehension test. The first question that showed the lowest percentage $(33 \%)$ is inference question. This question is about deducing information from the passage. Almost students at Insan Unggul Cilegon-Banten were difficult to answer inference questions. The second is vocabulary question $(40 \%)$. It is the question about closest meaning and determining meanings of difficult word.Next, it was the question about unstated detail $(50 \%)$. It is the question to find information that is not explicit in the passage. Reading carefully is essential to answer correctly to the questions.

\section{Results of questionnaire}

The following table presents the strategies that students used dealing with the reading comprehension. This results are gained from the questionnaire fullfiled by subjects of the research.

Table 2.1

Questionaire

\begin{tabular}{|c|c|c|c|c|c|c|c|c|c|c|}
\hline NO & $\begin{array}{c}\text { Statement of } \\
\text { reading } \\
\text { comprehension in } \\
\text { TOEFI test }\end{array}$ & $\begin{array}{l}\text { Strongly } \\
\text { agree }\end{array}$ & $\begin{array}{c}\text { Percent } \\
(\%)\end{array}$ & $\begin{array}{l}\text { Very } \\
\text { agree }\end{array}$ & $\begin{array}{c}\text { Percent } \\
(\%)\end{array}$ & $\begin{array}{c}\text { Dis } \\
\text { agree }\end{array}$ & $\begin{array}{c}\text { Percent } \\
(\%)\end{array}$ & $\begin{array}{l}\text { Strongly } \\
\text { disagree }\end{array}$ & $\begin{array}{c}\text { Percent } \\
(\%)\end{array}$ & $\begin{array}{c}\text { Total } \\
\text { Sum } \\
(\%)\end{array}$ \\
\hline 1 & $\begin{array}{l}\text { I used skimming and } \\
\text { scanning to find main } \\
\text { idea in TOEFL test }\end{array}$ & 9 & $45 \%$ & 5 & $25 \%$ & 4 & $20 \%$ & 2 & $10 \%$ & $100 \%$ \\
\hline 2 & $\begin{array}{c}\text { Inferring the } \\
\text { unfamiliar word is } \\
\text { easy to find out }\end{array}$ & 1 & $5 \%$ & 6 & $30 \%$ & 9 & $45 \%$ & 4 & $20 \%$ & $100 \%$ \\
\hline 3 & $\begin{array}{l}\text { Scanning is the } \\
\text { easiest way in } \\
\text { comprehending the } \\
\text { reading in TOEFL } \\
\text { test }\end{array}$ & 2 & $10 \%$ & 5 & $25 \%$ & 13 & $65 \%$ & & - & $100 \%$ \\
\hline 4 & $\begin{array}{l}\text { If I get difficulty in } \\
\text { getting main idea, I } \\
\text { usually used smart } \\
\text { guessing in particular } \\
\text { word. }\end{array}$ & 7 & $35 \%$ & 8 & $40 \%$ & 4 & $20 \%$ & 1 & $5 \%$ & $100 \%$ \\
\hline 5 & $\begin{array}{c}\text { Reading } \\
\text { comprehension is the } \\
\text { TOEFL is very easy } \\
\text { when I know already } \\
\text { the word wizard. } \\
\text { I like Reading }\end{array}$ & 9 & $45 \%$ & 5 & $25 \%$ & 3 & $15 \%$ & 3 & $15 \%$ & $100 \%$ \\
\hline 6 & $\begin{array}{l}\text { Comprehension due } \\
\text { to the ability in }\end{array}$ & 4 & $20 \%$ & 10 & $50 \%$ & 4 & $20 \%$ & 2 & $10 \%$ & $100 \%$ \\
\hline
\end{tabular}




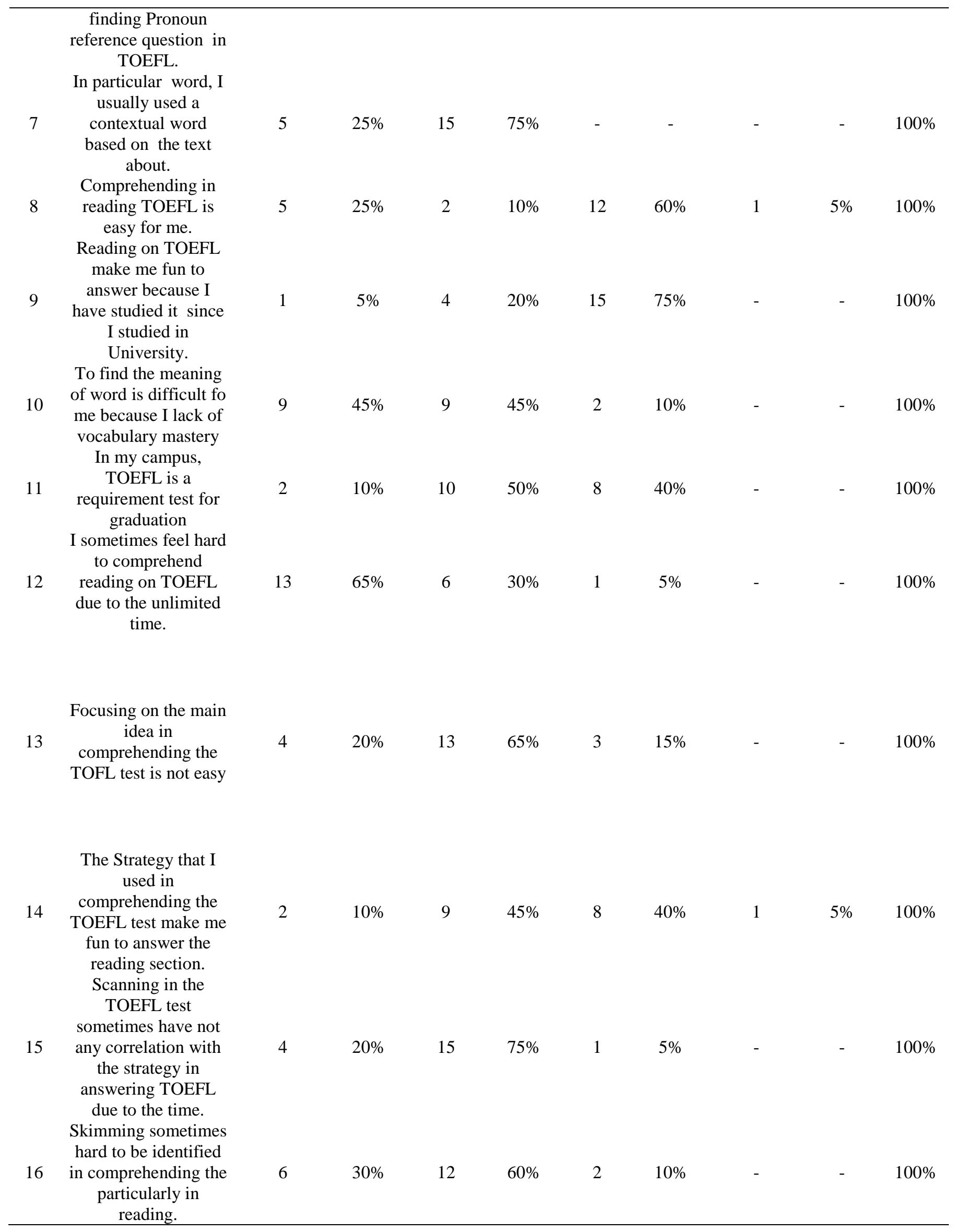


I always use a number of TOEFL

17 strategies in comprehending TOEFL, particularly in reading section.

The Strategies I used in completing the TOEFL test really boost up my score on TOEFL.

I look forward to finding out my reading grade in TOEFL

I sometime guessing in answering the unfamiliar word in TOEFL
5

$25 \%$

$$
8
$$

$40 \%$

2

$10 \%$

5

$25 \%$

$100 \%$

\section{7}

$35 \%$

13

$65 \%$

$-$

$100 \%$

6

$30 \%$

14

$70 \%$

$-$

$100 \%$

Total respondents
11

$55 \%$

\begin{abstract}
6
\end{abstract}
$30 \%$

2

$10 \%$

1

$5 \%$

$100 \%$

The most difficult types of question in TOEFL reading comprehension test

\begin{tabular}{clccc}
\hline No & Reading skill & $\begin{array}{c}\text { Total } \\
\text { Questions }\end{array}$ & $\begin{array}{c}\text { Correctly } \\
\text { answer }\end{array}$ & $\begin{array}{c}\text { Percentage } \\
(\%)\end{array}$ \\
\hline 5 & $\begin{array}{l}\text { Inference } \\
\text { question }\end{array}$ & 6 & 2 & $33 \%$ \\
7 & $\begin{array}{l}\text { Vocabulary } \\
\text { question }\end{array}$ & 10 & 4 & $40 \%$ \\
3 & $\begin{array}{l}\text { Finding } \\
\text { Unstated detail }\end{array}$ & 6 & 3 & $50 \%$ \\
\hline
\end{tabular}

From the table it is definitely seen that the most difficult types of question to be answered in TOEFL are number questions number 5. Inference question (33\%). Next, question number 7. Vocabulary question (40\%) This type of question covers $20 \%$ of the total questions in the TOEFL test, which suggests that vocabulary load and knowledge in reading are crucial (Pyle, 2001: 50). Lastly, followed by question number 3. Unstated detail $(50 \%)$ The examinees have to find information that is not explicit in the passage (Philips, 2001:385). 


\section{CONCLUSION}

In this chapter the researcher would like to draw some conclusions of what have been discussed in previous chapter. For achieve these expectation, students need to know the strategies and difficulties they might faced in this test. So, they should be aware of some strategies that can help them to reduce their problem and difficulties. Besides of the strategies, mastery vocabulary well was very crucial things for achieving a better score Based on research findings and discussions presented in the previous chapter several conclusions can be drawn. First, the students used simming and scanning to find main idea and specific information, top down for implied information and guess meaning for vocabulary question. The most difficult types of questions are inference question (33\%), vocabulary question (40\%), and unstead detail question $(50 \%)$. The greatest challenges for students in reading comprehension in TOEFL are lac of strategy, less motivation, and less practice. Third, the TOEFL score of STTIKOM Insan Unggul CilegonBanten was low. It could be seen from the result of test most of students got the score 320.

\section{REFERENCE}

Barneet, M.A. (1998) . Syntactic and Lexical Semantic Skill in Foreign

Language Reading Importance and Interaction. The Modern Language Journal, 70, 343-349.

Brown, H. Douglas. (2001a) . Teaching by Principle an Interactice

Approach to Language Pedagogy $\left(2^{\text {nd }} e d\right)$. New York : Addison Wesley Longman. Inc.

Brown, H. Douglas. (2007b). Principles of language learning and teaching. White plains, N.Y : Pearson Education.

Chern, C-1. 5. (1985). Chinese Students world - solving strategies in reading English. (master), Iowa

State University, USA.

Chames A.Ferguson. (1998). Memorial

Resolution : Standford Uniersity.

Chamot, A.u. (2004 a). Issues in Language

Learning Strategy Research and Teaching. Electronic Journal of Foreign Language e Teaching p. $12-25$.

Cohen, A.D \& Upton T.A . (2006). Strategies in Responding to the New

TOEFL Reading Tasks. (ETS Research Report No. RR-06-06). Pricenton, N.J : Educational Testing Service.

Cohen, A. D. And Macaro, E(eds). (2007)

. Language Learner Strategies.

Dreyer, C. And Oxford, R.L. (1996). Learning Strategies and other predictors of ESL Proficiency among Afrikaans Speakers in South Africa. In Oxford, R.L. (ed). 2001b. P.61-74.ETS. (2007). Document" Test and Score Sumary for TOEFL Internet Based

Test : September 2005-December 2006 Test Data" P.3, section “ History of the TOEFL Program.

Gerstein, R., Williams, J., Fuchs, L., \& Baker, s. (2001). Improving

Reading Comprehension for Children view of Educational 
ResearchDisabilities : A review of research. Review of educational research, 71, 279-320.

Grabe, W. \& Stoller, F.L. (2002). Teaching and researching Reading.

Harlo low Essex : Pearson

Education

Grabe, W. (2009) . Reading In a Second Language (Moving from theory

to practice). New York : Cambridge University Press. ISBN 978-0-521-72974-1.

Gani, S.A., yusuf, Y.Q., \& Susian, R. (2016). Progressive outcomes of collaborative strategies reading to EFL learners. Kasetsart Journal of Social Science, 3+(3), 144-149.

Hopkins, N.M \& Mackay, R. (1997). Good and Bad Readers : A look at

the high and low achiever Esp Canadian studies Reading and Writing course. The Canadian Modern Language Review, 53, 473-490.

Harrison, C. (2004). Understanding Reading Development. London : Sage Publication Ltd.

Hudson, T. (2007) . Teaching Second Language Reading. Oxford Universi versity Press.

Harmer, J. (2007) . How to Teach English ( Second edition ). Pearson

Education Limited, 288 pp., ISBN

9781405853095. Oxford University press.

Jimenez, R.T., Garcia, G.E \& Pearson, D.P. (1996). The Strategies of Bili

ngual Latin Students Who Are Successful English Reader: Opportunities and Obstacles.

\section{Reading Research Quarterly,} 31,90-112.

Koda, K. (2005). Insight into Second Language Reading. A Cross-

Linguistics Approach. New York: Cambridge University Press.

King, K. ( 2008 ). Reading strategies. Freely available at : http: // www. Isu. sedu/Kingkath/readstrt.html.

Karami, Hossein. (2008). Reading strategies : what are they? Journal of research in reading, 1-7. University of Tehran.

Kusuma, Al. (2016) . TOEFL Practice Test Toeic . Genta Smart Publisher Kheizardeh, S., \& Tavanoli, E. (2012). The causes of reading difficulty: the perception of Iranian EFL post graduate and undergraduate students. Journal of Language teaching and Research, 3 (1), 147152.

McDonough, S.H. (1995) . Strategy and Skill in Learning a Foreign Languge. London : Edward Arnold.

Mahmoud, A. (1992) . Error Based Interlinguistics Comparisons as learner Centered Technique of Teaching English Grammar to Arab Students. $\mathrm{PhD}$ diss., University of salford.

Mc. Namara, D. (2009) . The Importance of Teaching Reading Strategies.

Journal of Perspective on Language and Literacy. The International Dyslexia Association.

Mckee, steve. (2012) . Reading Comprehension, What We Know : A

review of research 1995 to 2011, p. $45-54$. 